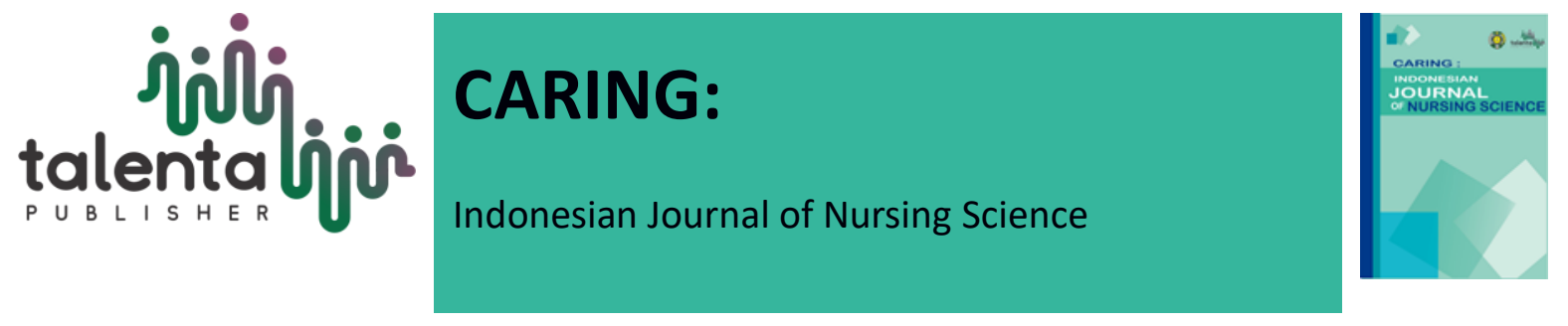

\title{
The Elderly Spiritual Description with Chronic Disease in Elderly and Children Social Services Centres of Binjai and Medan
}

\author{
Adelina Sembiring, Martaulina Sinaga, Lisbeth Gurning \\ STIKes Mitra Husada Medan
}

\begin{abstract}
The elderlies suffer from chronic diseases so that their spiritual needs need attention. This study aims to determine the spiritual description of the elderly who suffer from chronic diseases in the Social Service Unit for the Elderly Children under five in Binjai and Medan. The research design used was descriptive with a sample size of 64 people with the purposive sampling method. The instrument used was a questionnaire prepared using a Likert scale. This research was conducted from 28 November to 19 December 2014. The characteristics of the respondents and the spiritual description of the elderly who suffer from chronic diseases are described by descriptive analysis to determine the frequency and percentage. The results showed the characteristics of male respondents were $51.6 \%$, aged $60-70$ years $57.8 \%$, Islam $95.3 \%$, not going to school $59.4 \%$ Spiritual description of the elderly who suffer from chronic disease is quite good (56 people, $87.5 \%$ ), the elderly who say good ( 8 people, $12.5 \%$ ). To be able to undergo a declining health condition due to diseases suffered by the elderly, it is hoped that all parties, both families, health workers understand the spiritual needs of the elderly so that the elderly can accept their conditions, socialize with those around them, enjoy the natural beauty of their surroundings, and believe that God will give strength in living his condition.
\end{abstract}

Keywords. Spiritual, Elderly, Chronic Illness

Received 26 November 2020 | Revised 26 November 2020 | Accepted 31 December 2020

\section{Introduction}

The elderly is a phase of decreasing intellectual and physical abilities, which begins with several life changes. ${ }^{1}$ Aging is a normal process of change related to time, starting at birth, and continuing throughout life. ${ }^{2}$ Old age is the final phase of life, life span (Fatimah, 2010). ${ }^{4}$ Improvement in health quality and social conditions is an increase in life expectancy is reflected in the increasing number of elderly people from year to year. ${ }^{5}$

\footnotetext{
*Corresponding author at: STIKES Mitra Husada, Medan - Indonesia

Corresponding email: adelinasembiring91@gmail.com

Copyright (C) Published by Talenta Publisher, ISSN: 2580-6769 e-ISSN: 2580-829X

Journal Homepage: https://talenta.usu.ac.id/IJNS
} 
In 2012 , the number of elderly people was around 18.55 million or $7.78 \%$ of the total. the population of Indonesia (BPS, 2012). ${ }^{6}$ The number of elderly people in 2014 in North Sumatra was 631,604 people and the number of elderly people in Medan in 2014 was 77,837 people (Indonesian Statistical Data, 2014) . ${ }^{7}$

The increase in the number of elderly people will be followed by an increase in the risk of the elderly suffering from chronic diseases such as diabetes mellitus, osteoarthritis, gout, hypertension, and lung disease. ${ }^{8}$ About $50 \%-80 \%$ of the elderly who are $\geq 60$ years of age will suffer from more than one chronic disease. ${ }^{9}$ In Indonesia in 2008 the number of people with diabetes mellitus reached 17 million people, and the elderly who suffer from hypertension are around 15 million, while the elderly who suffer from Rheumatoid arthritis is around 56.2\% of the number of elderly people (Fatimah, 2010). ${ }^{10}$

Chronic illness that is prolonged and very rarely fully recovered greatly affects the elderly in terms of their spiritual needs because spiritual needs are the need to find meaning and purpose in life, the need to love and be loved and a sense of attachment, the need to maintain harmony or harmony with the outside world, struggling to answer or gain strength when dealing with physical illness (Hamid, 2000) .9 Spiritual as a multidimensional, which focuses on the purpose and meaning of life, while the religious dimension focuses more on the relationship of God Almighty.10 Spiritual as a twodimensional concept: vertical dimension is a relationship with God or the Highest that guides one's life, while the horizontal dimension is one's relationship with oneself, with other people, and with the environment (Young, 2007). ${ }^{11}$

Research conducted by Astaria in 2010 regarding Fulfilling the Spiritual Needs of the Elderly in Tanjung Gusta, Medan Helvetia District stated that 32.2\% of the spiritual needs of the elderly were in a good category, $61.3 \%$ of the spiritual needs of the elderly were in the fairly good category, $6.5 \%$ fulfillment of the spiritual needs of the elderly in the poor category and $0 \%$ of the spiritual needs of the elderly in the bad category. ${ }^{12}$ This data shows that the elderly are very concerned with their spiritual needs. At this time, the elderly can formulate positive personal meanings about the purpose of being in the world, develop the meaning of suffering and believe in a lesson from an incident/suffering, build positive and dynamic relationships through belief, self-confidence, and love. ${ }^{13}$ Elderly people will also be able to foster personal integrity and feel that they are valuable, feel a life that is directed towards them through hope, and be able to develop positive human relationships (Hamid, 2000). ${ }^{14}$ 
Spirituality has an important role in the development of well-being in people suffering from chronic diseases, spirituality allows a person "to make peace with the past, accept the current situation, maintain a positive outlook on life, and achieve life satisfaction (Young, 2007).$^{15}$

The results of observations made by researchers at the UPT Social Services for the Elderly and Children under five years of age in Binjai and Medan areas that 180 elderly people live in these places and all the elderly have complaints of chronic disease. ${ }^{16}$ From the description above, the researcher is interested in researching the spiritual picture of the elderly who suffer from chronic diseases at the Social Service Unit for the Elderly and Toddlers in Binjai and Medan Areas. ${ }^{17}$

\section{Research Method}

The research design used in this study is descriptive, which aims to determine the spiritual picture of the elderly who suffer from chronic diseases in the Social Services Unit for the Elderly and Toddlers in Binjai and Medan areas. ${ }^{18}$ The population in this study were the elderly who suffer from chronic diseases in the Social Service Unit for the Elderly and Toddlers in Binjai and Medan Region, amounting to 180 people. ${ }^{19}$ The sample is part or representative of the study (Arikunto, 2010). ${ }^{20}$ Based on the above calculations, the number of samples used in this study were 64 elderly people in the UPT of Social Services for the Elderly and Toddlers in Wilayah Binjai and Medan. ${ }^{21}$ This research was conducted at UPT Jasa. Social Elderly and Toddler Wialayah Binjai and Medan, with the consideration, that in this UPT there are many elderly people aged 60-80 years who suffer from chronic diseases so that it makes it easier for researchers to obtain data. Also, research on the spiritual description of the elderly in UPT Social Services and Children under five in Binjai and Medan areas has never been done before. ${ }^{23}$ 


\section{Research Result and Discussion}

Table 1 Distribution of Frequency and Percentage of Respondent Characteristics

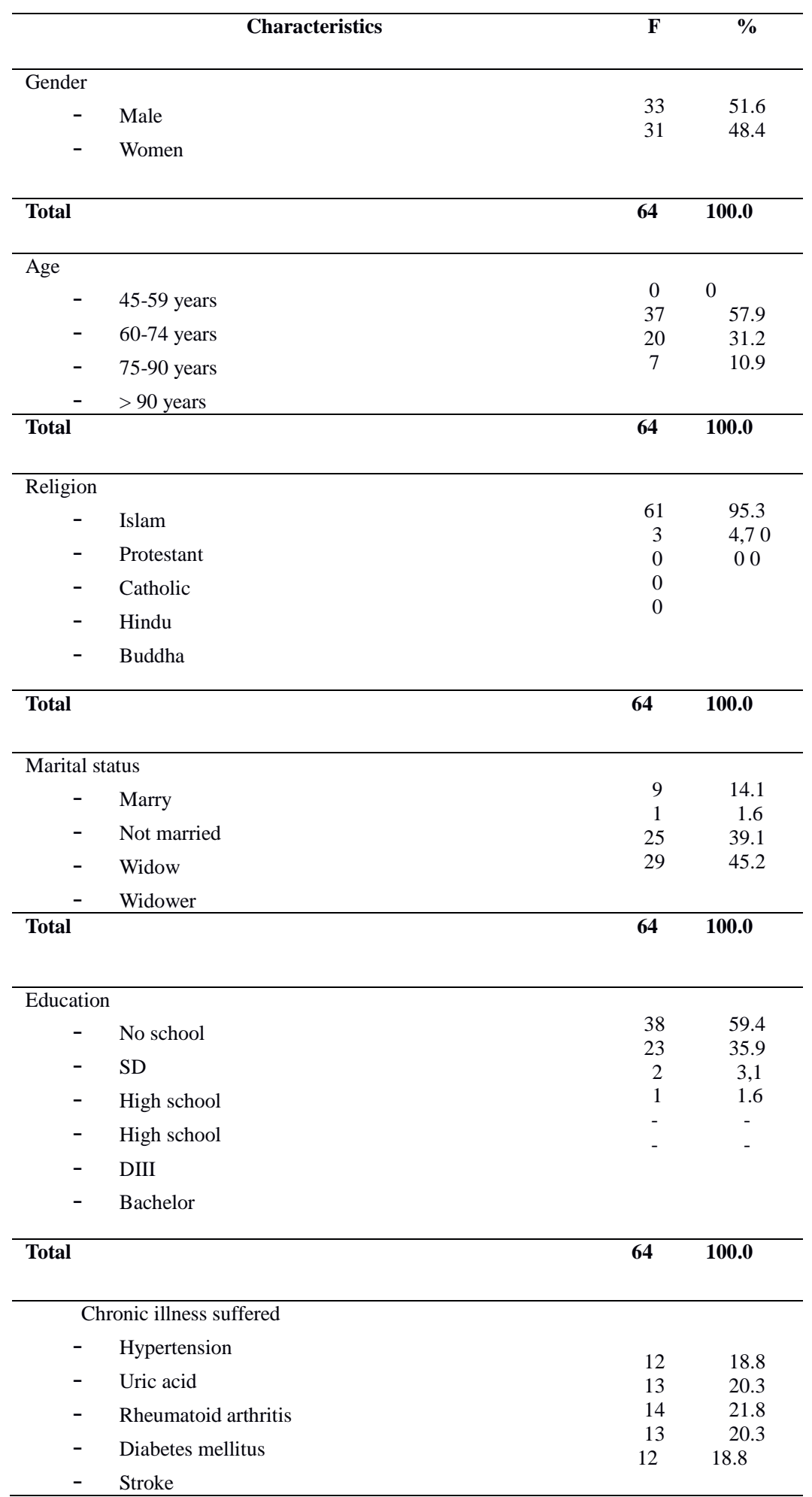

The frequency distribution table and the percentage of respondent characteristics (table 1) show that there are more male respondents than female respondents, namely 33 respondents $(51.6 \%)$ while female respondents are 31 respondents (48.4\%), and the age of the respondents is the most. 37 respondents (57.9\%) were in the 60-74 years range, 20 respondents (31.2\%) aged 75-90 years and 7 
respondents (10.9\%) aged $>90$ years. The majority of respondents are Muslim, namely as many as 61 respondents $(95.3 \%)$ while those who are Protestant Christians are as many as 3 respondents $(4.7 \%)$. Based on marital status, as many as 29 respondents (45.2\%) were widowers, 25 respondents $(39.1 \%)$ were widows and the rest 9 respondents $(14.1 \%)$ were married, 1 respondent (1.6\%) did not marry. Based on the respondent's education,

Table 2. Frequency Distribution and Percentage of Spiritual Descriptions of Elderly Suffering from Chronic Illness Based on Relationship with Self, Nature, Other People, and God $(n=64)$

\begin{tabular}{rlcc}
\hline Spiritual Imagery & F & \% \\
\hline- & Not good & 0 & 0 \\
- & Not good & 0 & 0 \\
- & Pretty good & 56 & 87.5 \\
- & Good & & 12.5 \\
\hline Total & & $\mathbf{6 4}$ & $\mathbf{1 0 0 . 0}$ \\
\hline
\end{tabular}

The results of the study of the spiritual description of the elderly who suffer from chronic diseases based on their relationship with themselves, nature, other people, and God, there were no respondents in the bad and bad categories, and 56 respondents (87.5\%) in good enough category, and well there are 8 respondents (12.5\%). The results of the study of the spiritual description of the elderly who suffer from chronic diseases at the UPT Social Services for the Elderly and Toddlers in Binjai and Medan Areas

\section{Conclusion}

The spiritual description of the elderly suffering from chronic diseases in the Social Services Unit for the Elderly and Toddlers in Binjai and Medan areas is in a fairly good category. Thing. From the demographic data, it can be seen that the characteristics of the respondents: male, 60-70 years old, Muslim religion, no school, widower status, rheumatoid arthritis.

The spiritual image of the elderly based on their relationship with themselves, nature, other people, and God is very much influenced by the health condition of an elderly person, so it greatly affects how an elderly person has a relationship with himself, such as believing wisdom from his condition, having the ability to solve his problems. And the relationship with nature that has limited movement due to the disease suffered, even relationships with other people by socializing with peers, and sharing about their condition, as well as the relationship with God, how to keep giving thanks to about conditions and keep praying about their conditions. 
To be able to undergo a declining health condition due to diseases suffered by the elderly, it is hoped that all parties, both families, health workers understand the spiritual needs of the elderly so that the elderly can accept their conditions, socialize with those around them, enjoy the natural beauty of their surroundings, and believe that God will give strength in living his condition.

\section{Suggestion}

Management officers and social workers at the UPT Social Services for the Elderly and Toddlers should strive to create an attitude of respect for parents by instilling the character and culture in caring for their parents as well as possible, with all the limitations inherent in the elderly, especially those who suffer from chronic diseases. The family as the closest person to the elderly should devote all their attention to the welfare of the elderly, especially their spiritual needs. A touch of affection can increase the self-esteem of the elderly. Spending time with the elderly can also make a valuable and valuable impression. This research can be the basis for examining the factors that can support the spiritual needs of the elderly. or as a study material to develop nursing interventions according to the spiritual needs of the elderly. Further research that can be done is to find or identify risk factors for spiritual distress in the elderly suffering from chronic diseases.

\section{Acknowledgement}

Authors would like to thank to all respondents who provide the researchers with valuable data during the data collection.

\section{Conflict of Interest}

There is no conflict of interest in this research result

\section{REFERENCES}

[1] Arikunto, S. (2010). Research Procedure A Practical Approach. Jakarta: PT. Rineka Cipta.

[2] Astaria, R. (2010). Fulfilling the Spiritual Needs of the Elderly in Tanjung Gusta Village, Medan Helvetia District: Thesis

[3] Fatimah (2010). Caring for Elderly Humans A Gerontic Nursing Process Approach. Jakarta: Trans Info Media.

[4] Hamid, AY (2000). Textbook of Spiritual Aspects of Nursing. Jakarta: EGC.

[5] http://www.datastatistikindonesia.com/portal/index.php?option=com_supas\&task=\&Itemid=9 72. Retrieved 8 September 2014.

[6] http://www.DepkesRI.com/portal/index.php?option=com supas\&task=\&Itemid=52. Retrieved 8 September 2014.

[7] Young, C, Koopsen, C. (2007). Spirituality, Health, and Healing. Medan: Pioneer Media Development. 